\title{
The Relative Efficacy of Reality Therapy Procedure in Reducing Indiscipline Among In-School Adolescents
}

\author{
Ojewola F. O. \\ Department of Guidance and Counselling, Adekunle Ajasin University, Akungba-Akoko, Nigeria \\ Email address: \\ fojewola@yahoo.com \\ To cite this article: \\ Ojewola F. O. The Relative Efficacy of Reality Therapy Procedure in Reducing Indiscipline Among In-School Adolescents. International \\ Journal of Vocational Education and Training Research. Vol. 2, No. 6, 2016, pp. 34-38. doi: 10.11648/j.ijvetr.20160206.11
}

Received: September 22, 2016; Accepted: November 23, 2016; Published: January 10, 2017

\begin{abstract}
The study investigated the effectiveness of reality therapy procedure in reducing indiscipline among in-school adolescents. The study adopted the pre-test, post-test, control quasi-experimental design using $2 \times 2$ factorial matrix. A total of 48 students were randomly selected from two secondary schools in Ogbomoso Township to participate in the study. A questionnaire titled Disciplinary Issues among Secondary School Students (DIASSS) was administered to the students to assess their indiscipline behaviour. Analysis of Covariance was used to analyze the two hypotheses raised. The result revealed that reality therapeutic technique proved effective in reducing indiscipline behaviour among the respondents. Significant difference was also found on the basis of gender. The result of the finding have far reaching implication for counseling psychologist, Educational administrator, policy makers and the Nigeria government.
\end{abstract}

Keywords: Indiscipline, Behaviour, Reality Therapy In-School, Adolescents, Gender

\section{Background to the Study}

The incidence of indiscipline has been the major issue plaguing many institutions of learning in the contemporary period. There are so many students who attend school without knowing why they are in the school. Many of them are in school without any ambition of what they actually want to become in life. Secondary schools are supposed to be a place where students' character are moulded and properly formed. Kwaja and Momah (2011) opined that students are expected to acquire knowledge, skills, experience, and discipline that will help them shapen their destiny and build them from what they used to be to what they intend to become. Many students' in the secondary school fall between the adolescent stage which is often characterized by physiologists as the period of stress and storm. The many changes that occur in the life of these adolescents could result into serious indiscipline and maladaptive behavioural pattern (Okobia \& Ohen, 2006; Oladele, 1998).

There are various acts of indiscipline often displayed by adolescents in the secondary school. Maphosa and Mammen (2011) observed that the issue of indiscipline among learners has taken the central place for a very long time both internationally and nationally. Olagunju and Ogunsanya
(2003) stated that the objective of discipline is to teach the child to conform to rules and regulations of the society, while failure to comply will amount to indiscipline which attracts punishment. Thornberg (2008) observed school discipline has all the strategies that can be used to coordinate, regulate and organise individuals and their activities in the school and to put in place provision and procedures necessary to establish and maintain an environment in which teaching and learning can take place. Discipline in school will enhance effective and efficient teaching and learning environment. Discipline is to bring about peaceful and harmonious school environment whereby the students will be able to learn in a serene and conducive environment. Zubaida (2009) opined that the main aim of discipline is to provide conditions which can promote learning. Discipline is meant to discourage disorderly conduct that may threaten safety in the classroom (Magwa \& Ngara, 2014).

There are different kinds of indisciplined behaviour common among adolescents in secondary school these ranges from truancy, lying, fighting, cursing, shouting, bullying and snatching of other learners' property, cheating, viewing of pornographic materials, threatening teachers among other 
deviant acts (Zubaida, 2009). The following are deviant behaviours that students exhibit frequently in classroom like walking out on the teachers, noise making, sleeping in the class, immorality, use of drugs and so on (Onyechi, Okere, \& Trivellor, 2007). In Nigerian schools, acts of indiscipline includes truancy, hooliganism disrespect for school authority, cheating in examination and drunkenness were on the increased in most secondary schools. Moseki (2004) found that truancy was rampant among high school pupils in South Africa, whereas in Zimbabwean schools, many cases of indiscipline abound. There are some schools in the area which have been turned into lawless institutions as pupils went unpunished for drinking and smoking in schools. Magwa \& Ngara, 2014; Ncube, 2013 also found cases of indiscipline in Zimbabwean secondary schools which were very widespread, ranging from minor cases like late coming, bullying and stealing to major cases like rape, murder and drug abuse. Students' misbehaviour is a prevailing problem affecting schools not only in Malaysia but also across the many nations around the world. (Yahaya, Ramli, Hashim, Ibrahim, Rahma, \& Yahaya, 2009).

According to Ngwokabuenui (2015), stakeholders have experienced magnificent increase in students' indiscipline in secondary schools in Cameroon. He further noted that there is an outcry by Cameroonian educators, administrators and parents about the increasing rate of indiscipline in Cameroonian secondary schools. This observation unsettles the mind of patriotic Cameroonians since children are considered the future leaders of the country. In Ghana, Ngwokabuenu (2015) decried the high rates of indiscipline and lawlessness in the educational institution. He observed that not a single day passes without a report of an act of indiscipline perpetrated by teenagers of primary and secondary schools. He lamented over the causes of drug abuse, rape, armed robbery, abortion, and even murder in educational institutions. There could be no more meaningful teaching and learning which are geared towards the attainment of successful academic outcome without proper discipline.

The issue of indiscipline is also gender related. Bingbam, Raymond, Shope, Jean and Raghunathan (2006) found that men had higher number of offenses than women. Underwood $(2002 ; 2003)$ asserted that girls are more likely than boys to engage in relational aggression which involves such behaviour as spreading of malicious rumour in order to get others to dislike a child or ignoring someone when angry at $\mathrm{him} /$ her. Okorodudu (2010) noted that gender is not a significant factor in adolescent deviant behaviour. He opined that boys with poor parental background may later graduate to become street boys, bus conductors or touts (area boys) often found in uncompleted buildings, motor parks and fighting along the street. (Mallum, Haggai \& Ajaegbu, 1999; Okpako, 2014; Otuadah, 2006). Whereas, Wu et al (1998) found no significant difference in delinquent behaviour between male and female adolescents. Sekuk, Rimfat and Ogbonna (2003) observed that until recently male adolescents were by far more involved in delinquent acts than females. But Okorodudu (2010) found that females are now getting involved in delinquent activities than in the past.

In order to help these students to reduce the incidence of indisciplined behaviour, there was the need to introduce an intervention strategy which is known as reality therapy. The basic goal of reality therapy is to help clients learn better ways of fulfilling their needs. The procedures which lead to change are based on two specific assumptions (Glasser, 1992). The first assumption is that their present behaviour is not getting them what they want, the second assumption is that humans are motivated to change when they believe that they can choose other behviours that will get them closer to what they want. Reality therapy emphasises the importance of the therapeutic relationship which is the foundation for effective counselling outcomes. Glasser (2000) asserted that many students lack good relationships with warm, caring, responsible adults. The most salient issue with choice theory is that human beings are driven by five basic genetic needs which are survival, love, belonging, freedom, fun and power (Glaser, 2000).

\subsection{Statement of the Problem}

The increasing level of indiscipline among adolescents in secondary school is now becoming alarming. This is causing lots of concern to stakeholders in the educational sector worldwide. The level of indiscipline varies from one nation to the other but the reviewed literature indicated that this issue has become global concern to the generality of people. In the United States the National Centre for Educational Statistics revealed that in (2006) thirty six percent (36\%) of the students in grades 9-12 reported that they had been in a physical fight within the last year. It is further added that 4 percent $(4 \%)$ of Inner City teachers and 3 percent $(3 \%)$ of suburban and rural teachers were physically attacked by students (Deaukee, 2010).

The level of destruction in secondary school is becoming worrisome. This is actually adversely affecting the teaching and learning activities in schools. This is supported by the assertion of Kuntz (2000) that everyday primary and secondary school teachers in both private and state sectors are being confronted with bad behaviour, destruction of school equipment or furniture, pupils' lack of respect for each other or for adults which often impede normal school routine. Lawlessness and disorderliness have become the order of the day in most secondary schools in the contemporary period. Indiscipline has eaten deep into every facet of the school life Indiscipline is not only found among students even teachers are often seen displaying this negative behaviour even within the school setting

Although many research work were carried out on indiscipline in secondary schools by Idu \& Ojedapo, (2011); Ibukun, (2003); Zubaida, (2009), many of this research work did not provide solution to this problem of indiscipline among adolescents. This research work intends to fill the gap left by seeking solution on how to reduce the incidence of indiscipline among adolescents in secondary schools. With the escalating level of indiscipline, teachers are finding it 
more challenging to create orderly environment. Administrators are also complaining of having to spend too much time dealing with indiscipline issues (Deaukee, 2010). Therefore this research intends to make use of reality therapy as an intervention strategy to reduce the incidence of indiscipline behaviour among secondary school adolescents.

\subsection{Purpose of the Study}

The purpose of this study was to find out whether Reality therapy will have significant effect in reducing indiscipline behaviour among students. The study was also to determine the effect of gender on indiscipline among students

\subsection{Hypotheses}

The hypotheses in the study are:

1. There is no significant difference in the reduction of indiscipline behaviour between participants in the experimental and control groups.

2. There is no significant difference in the reduction of indiscipline between participants in the experimental and control groups on the basis of gender.

\section{Methodology}

This study is a quasi- experimental group design using the pre- test, post- test and control. The design utilized a $2 \times 2$ factorial matrix.

Table 1. Randomisation into experimental and Control groups.

\begin{tabular}{llll}
\hline Treatment condition & Male & female & Total \\
\hline Reality Therapy & 12 & 12 & 24 \\
Control & 12 & 12 & 24 \\
Total & 24 & 24 & 48 \\
\hline
\end{tabular}

The participants were randomly assigned into two groupsexperimental and control groups. Those in the experimental group were exposed to reality therapy strategy while those in the control group were taught how to develop effective study habits.

\subsection{Sample and Sampling Procedure}

Two public schools were randomly selected from Ogbomoso North Local Government. Since indiscipline is a general behavioural problem in all the schools in the zone. The researcher decided to randomly select these two schools for this research effort. One of the school was used for the experimental group while the second was used for the control group. The researcher made use of purposive sampling procedure to select the schools. In selecting the participants the researchers went through the class teachers, class captains, school counselors and the administrative staff to selects participants, for the research work. Students with disciplinary issues were identified in each of the schools used. These students were administered with questionnaire titled Disciplinary Issues among Secondary School Students.
(DIASSS). The result from the questionnaire were used to identify those that needed to be enlisted for the experimental procedure. Thus, these students were identified and randomly assigned into the experimental and control group.

\subsection{Treatment Group}

Respondents in the experimental group were exposed to eight weeks of intensive training strategy on reality therapy. There were eight session of one hour duration each.

Session 1: General orientation to the training programme. There was the need to build relationship with the clients. This was done by creating a safe and warm environment. Avoid coercion and punishment; there was need to express genuine concern and empathy

Session 2: There was the need to introduce the concepts of choice theory.

Session 3: The concept of choosing one's behavior was introduced. Clients were taught to choose positive and enhancing behaviours instead of the negative unproductive behaviour.

Session 4: Discussion on what they want in life was put before them. This will help them to develop positive and worthwhile behaviours.

Session 5: Discussion on what they could do to get what they want. To succeed and make it in life, worthwhile behaviours and attitudes are necessary.

Session 6: The following question must be sincerely answered- is what you are doing working? There was the need for self -evaluation of their behaviour.

Session 7: The student should be able to provide alternative ways of doing things right. This involves another way to get what they want.

Session 8: (A) Students should display behaviour that that will enhance good discipline.

(B) Administration of the post- test

(C) Evaluation of the treatment package.

Control group - They were equally exposed to the following packages.

Session 1: Orientation programme.

Session 2: What is study habits?

Session 3: How to enhance good study habits

Session 4: Reading for examination.

Session 5: What is the relationship between reading and remembering?

Session 6: How to read and prepare for examination.

Session 7: How to answer examination questions.

Session 8: How to read and understand.

\subsection{Data Analysis}

The data collected from the pre and post test scores were analysed using analysis of Covariance.

Hypothesis 1: There is no significant difference in the reduction of indiscipline behaviour between participants in the experimental and control groups. 
Table 2. ANCOVA table comparing the performance of respondents' in the experimental and control groups.

\begin{tabular}{llllll}
\hline Source of Variation & Sum of Square & Df & Mean Square & f.cal & f critical \\
\hline Rows & 7659.1 & 1 & 7669.1 & 247.6 & 4.055 \\
Columns & 1607.3 & 1 & 1607.3 & 52.0 & \\
Interaction & 9266.4 & 2 & 4933.2 & 150 & \\
Within & 1391.9 & 45 & & & \\
\hline
\end{tabular}

*Significant at $\mathrm{p}<0.05$.

The result on table 2 shows that significant difference existed between the scores of respondents that were exposed to the treatment of (Reality therapy) and those in the control group as a significant $f$ value of $(\mathrm{f}=247.6$; df $1 / 45: \mathrm{p}<0.05)$ was obtained.

Hypothesis 2: There is no significant difference in the reduction of indiscipline behaviour between the participants in the experimental and control groups on the basis of gender.

Table 3. ANCOVA table for the comparison of the respondents' in both the experimental and_control groups on the basis of gender.

\begin{tabular}{lllll}
\hline Source of variation & Sum of Square & Df & Mean Square & f. cal \\
\hline Rows & 7659.1 & 1 & 7659.1 & 240.6 \\
Columns & 1607.3 & 1 & 1607.3 & 50.5 \\
Interaction & 16.5 & 1 & 16.5 & 0.50 \\
Within & 1368.7 & 43 & 2322.4 & 31.8 \\
\hline
\end{tabular}

*Significant at $\mathrm{p}<0.05$.

The result on table 3 shows that a significant difference existed between the scores of the respondents in both the experimental and control groups on the basis of gender. Therefore, the null hypothesis of no significant difference was rejected. The calculated $\mathrm{f}$ was found to be greater than the table valve (f 240.6 , df $1 / 43, \mathrm{p}<0.05$ ).

\section{Discussion}

The result of the first hypothesis indicated that significant difference existed between the scores of respondents exposed to the experimental group and those in the control groups. The respondents exposed to the reality therapy procedure performed better than those who were not exposed to the treatment package. The result of this finding is in consonance with the result of Agali (2004) that found reality therapy effective in assisting prison inmates adjust to life after prison. Madukwe, Echeme, Njoku, Annorzie, Omagam and Nwufo (2016) also utilized reality therapy in the treatment of bullying among adolescents and it was found to be efficient in reducing bullying. The result of this study supports the findings of Barker (1995) that reality therapy can help to reduce adolescent temperament and make them stay out of trouble. Melisa (2010) also found that reality therapy is effective in treating high school delinquency. Basically, reality therapy was found to be effective in addressing indiscipline behaviour among students probably because the package is client friendly and its centres on helping clients to develop alternative desirable behaviour.

The result of the second hypothesis indicated that a significant difference existed between the scores of respondents in both the experimental and control groups on the basis of gender. The findings run contrary to the result of Ojewola (2014) that found that gender was not effective in the influence of media violence on aggressive behaviour among secondary school students. Odu, Alokan, Ibimiluyi,
Iretor, Oluwaseun and Olotu (2015) equally found that gender did not influence aggressive behaviour, truancy and child abuse among secondary school students. Whereas, Okorodudu (2010) observed that men had higher numbers of offence than woman. Sekuk, Rimfat, and Ogbonna (2003) found that until recently male adolescents were by far more involved in delinquent acts than females.

\section{Conclusion}

It was concluded from the results gathered from the hypotheses tested that -

-Significant difference exists between the scores of respondents' exposed to reality therapy and those in the control group.

-Significant difference exists between the scores of respondents in both the experimental and control groups on the basis of gender.

\section{Implications for Counselling Education}

The findings of this research effort has the following implications. Counsellors must be employed at all levels of the educational sectors right from the primary to secondary schools so as to reduce the incidence of indiscipline behaviour. Counselors should be properly trained to handle reality therapy procedures to help students with indiscipline issues.

Parents' must make sure that their children are properly trained to reduce indiscipline in schools. Improper training at home will adversely affect children's behaviour in schools; hence parents should not abrogate their responsibilities over their children to the school authorities alone. Parents should seek audience with school administrators and counsellors to help their erring children especially those with indiscipline problems. 


\section{References}

[1] Agali, P. O. (2004). Relative efficacy of reality therapy and the life after prison in - mates adjust to the life after prison unpublished $\mathrm{PhD}$ thesis, University of Ilorin, Kwara state.

[2] Barker, A. (1995). Success of emotional disturbed adolescents in therapeutic wilderness. Houston: State University Press.

[3] Biagham, Raymond, Shope, Jean, T, \& Raghunathan, T. (2006). Patterns of traffic offenses from adolescent licensure into early young adulthood. Leisure Sciences 39, 35-45.

[4] Deaukee, L. (2010). Students' perception of indiscipline at three primary school in one educational district in Central Trinidad, An unpublished M. Ed. thesis, University of the West Indies.

[5] Glasser, B. (1992). Basic of grand theory analysis. California, Sociology Press.

[6] Glasser, B. (2000). Counselling with choice theory the new reality therapy. New York: Harper Collins.

[7] Ibukun, W. O. (2003), Maintaining discipline in primary school system in Nigeria. Nigeria Journal of Counselling and Development 2, 132- 142.

[8] Idu, A. P. \& Ojedapo, D. O. (2011). Indiscipline in secondary schools: A cry to all stakeholders in Education. Proceedings of the 2011 International Conference on Teaching, Learning and Change, 729-735.

[9] Kuntz, L. I (2000). Unruly classroom. The UNESCO Courier. Retrieved from http://www.unesco.org/courier/200001/uk/apprend/txt.html.

[10] Kwaja, P. \&. Mormah, F. (2011). Managing adolescents' maladaptive behaviour in Nigeria secondary schools International Journal of Research Development 4 (1) 1-9.

[11] Madukwe, A. U, Echeme, J. O Njoku, Annorzie; Omagamne, U. R \& Nwufo, I. (2016). Effectiveness of reality therapy in the treatment of bullying among adolescent in Owerri, North, Imo State, Nigeria. British Journal of Education Society and Behavioural Sciences 15 (4) 1-8.

[12] Magwa, S. \& Ngara. R. (2014). Learner indiscipline in schools. Review of Arts and Humanities 3 (2), 79-88.

[13] Mallum, T. O., Haggai, M. P. \& Ajaegu, K. J. U. (1999). An introduction to child development. Jos: Deka Publication.

[14] Melisa, D. (2010). High School delinquency. London: Routledge Press.

[15] Moseki, M. (2004). The nature of truancy and the life world of truants in secondary schools, university of South Africa. Unpublished M. Ed. thesis, University of South Africa.

[16] Ncube, B. (2013). Parental involvement in school discipline. Harare College Press.

[17] Ngwokabuenui, P. Y. (2015). Students indiscipline: Types causes and possible solution: the case of secondary school: Cameroon Journal of Education and Practice 6 (22) 64-72.

[18] Odu, B. K., Alokan, F. B., Ibimiluyi, F. \& Iretor, O. A. (2015).
Influence of gender and age on behavioural problems and experience of child abuse among secondary school student. British Journal of Education 13 (10), 22-34.

[19] Ojewola, F. O. (2014). The influence of family condition, gender and age on the aggressive behaviour of adolescents prone to violent media in Ogbomoso, Nigeria. European Scientific Journal 10 (32) 144-155.

[20] Okobia, D. O. \& Ohen E. R. (2006). The substance of adolescent psychology Agbor: Krishec Publications.

[21] Okorodudu, G. N. (2010). Influence of parenting styles on adolescent delinquency in Delta central senatorial district. Edo Journal of Counselling 3 (1), 58-86

[22] Okpako, J. E. F. (2004). Parenting the Nigerian adolescents: Towards smooth transition to adulthood in contemporary issue and research in adolescents. (I. A.) Nwazuoke, O. Bamgbose \& O. A. Morokola (Ed) Ibadan Omoade Printing Press.

[23] Oladele, J. O. (1998). Fundamental of psychological foundation of education: Handbook for education students and teachers. Surulere: Mainland Bureau.

[24] Olagunju O. P. \& Ogunsanya, E. A. (2003). Discipline as a panacea to qualitative education: The perception of teachers. The counsellor 19 (2), 1-174.

[25] Onyechi, K. C., Okere, A. \& Trivellor, U. (2007). Deviant behaviour as correlate of academic achievement among secondary school adolescents: Implication of service delivery in the educational sector, Issues and Strategies. B. G: Nworugy.

[26] Otuadah, C. E. (2006). Parental behaviour among and peer group influence as correlates in Warri metropolis. Unpublished M. Ed. thesis of Delsu, Abraka.

[27] Sekuk, R. T.; Rimfat, D. Z. \& Ogbonna, B. B. (2003). Prevalence of delinquent behavour among adolescents: Implication for counselling. The Behaviour problems of the Nigerian society for Educational Psychologist (NICEP) Edited by R. Onwukwe Nnachi \& P. S. E. Ezeh, 59-68.

[28] Thornberg, R. (2008). School children's reasoning about school rules. Research Papers in Education 23 (1), 37-52.

[29] Underwood, D. M. (2003). Social aggression among girls in New York: Guildford Press

[30] Underwood, M. (2002). Sticks and stones and social exclusion: Aggression among boys and girls In P. K. Smith \& C. Hart (Eds), Blackwell handbook of childhood social development Oxford, UK: Blackwell.

[31] Wu, chia, Lee Shin Yng \& Lee Yuch Wun. (1998). Factors affecting adolescent delinquency in Singapore www.z.ntu.edu.sg/nbs/Sabre/working-paper.

[32] Yahaya, A., Ramli, J., Hashim, S., Ali Ibrahim, M. J., Abd Raahman, R. R. R. \& Yahaya, N. (2009). Discipline problems among secondary school student in Johox Bahru, Malaysia. European Journal of Social Sciences 11 (4), 659-674.

[33] Zubaida, A. N. (2009). Indiscipline and its management techniques: A case study of a special education schools Kano State. The Journal of the National Council for Exceptional Children 11 (2), 455-463. 